abroad. It is in China's interests to ensure that its national needs are kept in mind and that China, at least in the foreseeable future, has only a small export market for its educational programs and institutions.

It is not at all clear that accredited but low-quality foreign colleges and universities are serving students or the Chinese academic system well. There should be a working system to evaluate foreign academic institutions seeking to enter China-including a thorough assessment of quality and an understanding of the position of the institution in its home environment. Such an arrangement, set up by Chinese researchers or with assistance from objective foreign experts, could help to evaluate potential foreign partners. Singapore, for example, has developed a list of overseas institutions considered appropriate for government-sponsored scholarships or other collaborative higher education programs.

Consideration should be given to the institutional motivations as well as the terms and conditions of any agreements with foreign partners or schools desiring to work in China. Is a foreign institution offering its best quality programs and staff? Is there appropriate accountability for performance? Do the programs offer more than the prestige of an international linkage? Is staff and institutional development part of the agreement? What is the "business plan" of the foreign provider? Questions need to be asked to ensure that the best interests of the host institution and the students are well served.

It is likely that in some cases local institutional or government authorities may fail to adequately examine overseas collaborations or may lack the expertise to make appropriate judgments. National or at least provincial agencies should have

China is not alone in facing difficult decisions concerning foreign academic relationships

authority to review overseas programs. The review process should be as transparent as possible.

Decisions concerning foreign academic relationships or granting permission to foreign institutions to operate in a country are important. They have significant implications for the local higher education community - a good partner can bring new ideas and good quality education. An ineffective link may be costly to host institutions. And perhaps most relevant, students may not be well served. China is not alone in facing difficult decisions concerning foreign academic relationships. India, Malaysia, South Africa, and other countries find themselves in similar circumstances in an increasingly globalized world of higher education. Despite an internationalized environment, higher education remains a key responsibility of nations to supervise to ensure that their national interests are served and both access and quality are preserved.

\section{Internationalizing Higher Education in South Africa}

\author{
Ariel Libhaber and Ryan M. Greene
}

Ariel Libhaber is an education policy analyst and consultant to the Education Policy Unit at the University of the Witwatersrand, and a research associate at Brandeis University. E-mail: libhaber@brandeis.edu. Ryan M. Greene is an ABD visiting scholar at the Faculty of Education at the University of Pretoria and a PhD candidate in international education policy studies at the University of Maryland, USA. E-mail: rmgreene@umd.edu.

A partheid clearly left a very unequal higher education sysAtem of privileged and disadvantaged institutions. However, in just over Io years we find a changing scenario of newly formed inclusive public universities, universities of technology, and a growing number of private institutions responding to a new market.

\section{The AdVent Of Internationalization}

One of the most salient features of this new context of higher education involves coming out of isolation and joining the global community. South African higher education has clearly been developing new international paradigms, programs, and relationships. Lately, the country has also become a favored destination for foreign students, mainly from other parts of Africa, seeking postgraduate degrees and better job opportunities. The number of international students studying in South Africa stood at about I4,I24 foreign nationals in I995. However, the number rose sharply over the recent decade to stand at 46,687 in 2002 , representing a total of 7 percent of the entire higher education enrollments. A new market has opened for local institutions that perceive the influx of international students as both a source of diversity and revenue for their campuses.

As part of the realities of globalization, higher education faces increasing pressure to compete both locally and internationally: for better students, faculty, funding, and research opportunities. South African higher education, as most systems of higher learning around the world, falls under the open-market ideas of the General Agreement on Trade in Services. This and other market forces have clearly impacted on expansion of the private higher education sector and the new funding constraints in the public sector.

As the education market expands, so does the demand for other products-leading to the growth of the private sector. However, private institutions comprise only a low percentage of the nation's enrollments, mostly attracting white students seeking an alternative route into the job market or degrees they can use overseas-since most degrees offered are in the areas 
of business and management.

Internationalization is not only an inward process; many white students enter both the public and private system hoping to acquire internationally marketable skills (such as business, medicine, or teaching) they can use elsewhere, especially in developed English-speaking countries.

\section{INTERNATIONALIZATION TRENDS}

While dealing with this intersection of the local, national, regional, and global sectors, South Africa is still struggling to decide just what role it will play. Nevertheless, higher education institutions are pushing ahead to create more internationalized campuses by attracting international students, faculty, and staff through a variety of programs and partnerships.

For example, the University of Pretoria's Faculty of Education has signed reciprocal partnerships with institutions in countries like Namibia, Mozambique, and the Netherlands; and relationships are also being explored with institutions in countries like China and Japan. Many of these agreements deal with contracts covering the exchange of students and faculty members between institutions. In addition, the UNESCO Centre for Capacity Building in Africa is housed within the same faculty, which has also been the site of various international academic conferences.

Attracting international students, although a common phenomenon in Europe and the United States, has particularly expanded over the last few years in South Africa. Foreign students who come here are seduced by the institutions' international reputation, wide curriculum options, lower tuition and living costs (compared to Europe and North America), location, and the advantage of having English as the medium of instruction. However, international partnerships and exchange programs have been taking place for a long time, although in a haphazard way. The difference now is that institutions are realizing that if they want to become truly competitive in the international arena, they must implement formal internationalization policies; and this is easier said than done at many his-

\section{As part of the realities of globalization, higher edu- cation faces increasing pressure to compete both locally and internationally: for better students, fac- ulty, funding, and research opportunities.}

torically disadvantaged institutions in South Africa. At more privileged institutions, internationalization is happening at a quicker rate. In 2004 the University of the Witwatersrand took on an extensive institutional survey as part of a renewed strategy for internationalization, along with specific funding and roles assigned to the deputy-vice chancellor and an improved international office. Similar international offices serving as pivotal centers for internationalization exist in institutions such as the University of Johannesburg, Stellenbosch University, and the Mandela Metropolitan University; and these are only some of the institutions reviewing internationalization policies to integrate them in their academic planning, curriculum, research agendas, and enrollment goals. Some institutions such as the University of Cape Town also have agreements with numerous universities around the world for coursework, to attract both local students with an internationally recognized degree and foreign students with a semester abroad or even a full degree. The University of KwaZulu-Natal, for example, advertises the advantages of an internationally recognized degree at a fraction of the cost of American or European feeshighlighting the privileges that students from the Southern African Development Community receive by qualifying to pay local fees, thus creating a further incentive for African students from the region.

\section{Attracting international students has particularly} expanded over the last few years in South Africa.

\section{CONCLUSION}

For many institutions, internationalization is slowly turning into integrated policies-impressive numbers of international students and staff, as well as coordinated exchange programs and multilateral partnerships with academic institutions and private organizations.

Although the South African government has not created a clear policy framework for internationalizing higher education, it has promoted the significance of achieving rich diversity on its campuses and, more importantly, establishing better partnerships and collaborations to improve research outputs, infrastructure, and industry. With economic competitiveness in mind as well as the development of the region, South Africa seems to expect higher education would lead the way in knowledge production, skills development, and capacity building. One way toward achieving these goals is creating centers of excellence that will attract researchers and reduce the brain drain. As of this writing, such centers are in the developmental stage.

Probably the hardest challenge for South African institutions in this complex context of globalization, where different economic and social forces overlap, will have to do with the tensions between trying to be globally competitive, while at the same time retaining their local identity and commitment to social development in the region. 